Volodymyr Stepashko, Andrii Trachuk

\title{
DEVELOPMENT OF FORECASTING SCENARIOS OF THE ELECTRICITY CONSUMPTION IN UKRAINE BY USING THE GROUP METHOD OF DATA HANDLING
}

Володимир Степашко, Андрій Трачук,

\section{РОЗРОБКА ПРОГНОЗНИХ СЦЕНАРІЇВ СПОЖИВАННЯ ЕЛЕКТРОЕНЕРГІЇ В УКРАЇНІ ШЛЯХОМ ВИКОРИСТАННЯ МЕТОДУ ГРУПОВОГО УРАХУВАННЯ АРГУМЕНТІВ}

\author{
Владимир Степашко, Андрей Трачук \\ РАЗРАБОТКА ПРОГНОЗНЫХ СЦЕНАРИЕВ ПОТРЕБЛЕНИЯ \\ ЭЛЕКТРОЭНЕРГИИ В УКРАИНЕ ПУТЕМ ИСПОЛЬЗОВАНИЯ МЕТОДА \\ ГРУППОВОГО УЧЕТА АРГУМЕНТОВ
}

Розглянуто проблемні питання споживання електроенергії по Україні. Проаналізовано динаміку споживання електроенергії та запропоновано методичні рекомендації щодо ефективного використання електроенергії. Досліджені прогнозні сиенарії споживання електроенергії загалом по всій Украйні. Базовою основою формування енергосистеми Украӥни є побудова прогнозних сиенаріїв за різними видами енергоресурсів та різноманітними критеріями ефективного використання паливно-енергетичних ресурсів. Проблема ефективного використання паливноенергетичних ресурсів постає дуже важливою для сталого економічного розвитку енергетики на фоні збереження залежності національної економіки від імпорту енергоносіїв, а також зростання цін на дані ресурси. Вирішення иієї проблеми пов 'язано не тільки з забезпеченням енергетичної безпеки крайни, але також із підвищенням рівня розвитку регіонів краӥни та забезпечення якості життя його населення.

Ключові слова: енергетичний баланс; енергозбереження; енергоефективність; енергетична статистика.

Табл.: 7. Бібл.: 6.

Рассмотрены проблемные вопросы потребления электроэнергии по Украине. Проанализирована динамика потребления электроэнергии и предложены методические рекомендации относительно эффективного использования электроэнергии. Исследованы прогнозные сиенарии потребления электроэнергии в целом по всей Украине. Базовой основой формирования энергосистемы Украины является построение прогнозных сценариев по различным видам энергоресурсов и разнообразным критериям эффективного использования топливно-энергетических ресурсов. Проблема эффективного использования топливно-энергетических ресурсов возникает крайне важной для устойчивого экономического развития энергетики на фоне сохранения зависимости национальной экономики от импорта энергоносителей, а также рост иен на данные ресурсы. Решение данной проблемы связано не только с обеспечением энергетической безопасности страны, но также с повышением уровня развития регионов страны и качества жизни его населения.

Ключевые слова: энергетический баланс; энергосбережение; энергоэффективность; энергетическая статистика.

Табл.: 7. Библ.: 6.

Considered problem issues of electricity consumption in Ukraine. The dynamics of energy consumption and the proposed guidelines gait efficient use of electricity. Researched and projected scenarios projected electricity consumption in general throughout Ukraine. The basic foundation of the formation of the Ukraine grid construction is forecasting scenarios for different types of energy and the various criteria for effective use of energy resources. The problem of efficient use of energy resources raises crucial for sustainable economic development against the backdrop of energy saving national economy depends on energy imports, on the one hand, and rising prices for these resources. The solution to this problem is not only with ensuring energy security, but also with the level of development of regions and the quality of life of its population.

Key words: energy balance; energy conservation; energy efficiency; energy statistics.

Tabl.: 7. Bibl.: 6.

Introduction. Forecasting of electricity consumption in Ukraine today is an extremely important issue of strategic importance because due to conducted analysis and build predictive models may be developed guidelines for efficient production and consumption across Ukraine as a whole.

The aim of the work is to develop a methodological provisions for forecasting electricity consumption in Ukraine through the use of Group Method of Data Handling.

Statement of main material and research results. The level of energy has a decisive influence on the development of the state economy, solving social problems and living standards of citizens. Changes in energy prices immediately displayed in all industries, and the rest, the price of the final product. Therefore, instead of quantitative objectives of energy develop-

(C) Степашко B. С., Трачук А. Р., 2017 
TECHNICAL SCIENCES AND TECHNOLOGIES

ment, which was followed by Ukraine's economy in recent decades, energy has to go to power sustainable economic development, the targeted today developed countries. The said research leads scientists to balance the energy balance of Ukraine, which determined the relevance of the work. In the traditional understanding of energy balance is like the relation between extraction (production) and consumption of different types of energy resources.

The formulation of energy balance is a complex strategic statements of economic development, the definition of forecast consumption of energy based on adopted policies to increase energy efficiency, the development of the fuel and energy sector and assess options extraction and production of fuel and energy, as well as forming lines import- export policy and determine the volume of purchase and sale of energy.

One of the mathematical methods of forecasting is group method of data handling that allows you to build adequate models predicted energy consumption energy balance in the system of Ukraine.

By using the Group Method of Data Handling and by using modern software were built prediction models of energy resources in the system of energy balance of Ukraine:

1. Projected system model prediction for next year depends on the values for the previous year, offset $(-1)$ :

$$
\begin{aligned}
& \mathrm{Y} 1=89,726+0 * \mathrm{Y} 1(-1)-12,174 * \mathrm{Y} 2(-1)+0 * \mathrm{Y} 3(-1) \\
& \mathrm{Y} 2=0,3592+0 * \mathrm{Y} 1(-1)+0 * \mathrm{Y} 2(-1)+1,3623 * \mathrm{Y} 3 \\
& \mathrm{Y} 3=0,0000+0 * \mathrm{Y} 1(-1)+0 * \mathrm{Y} 2(-1)+1.0149 * \mathrm{Y} 3(-1) .
\end{aligned}
$$

Comment: Y1 (Final energy consumption (FEC), ths. $t$ o.e.) Depends on Y2 (-1) (last year) and Y2 (primary energy intensity (total primary energy supply, t o.e. / $€ 1000$ GDP)) in turn by Y3 (-1) last year - that Y1 and Y2 do not include auto regressive components; This model is for purely autoregressive Y3: Y3 (final energy consumption (final energy consumption t o.e. / $€ 1000$ GDP)) depends on its previous value Y3 (-1).

Initial data for forecasting final energy consumption are presented in Table 1.

Table 1

\section{Initial data of final energy consumption}

\begin{tabular}{|c|c|c|c|}
\hline \multirow{2}{*}{ Year } & $\begin{array}{c}\text { Final energy } \\
\text { consumption (FEC) } \\
\text { ths. t o.e. }\end{array}$ & $\begin{array}{c}\text { Primary energy intensity (total } \\
\text { primary energy supply, t o.e. / } \mathbf{\epsilon} \text { 1000 } \\
\text { GDP) }\end{array}$ & $\begin{array}{c}\text { Final energy consumption } \\
\text { (final energy cons umption } \\
\text { t o.e. / } € \text { 1000 GDP) }\end{array}$ \\
\cline { 2 - 4 } & Y1 & Y2 & Y3 \\
\hline 2006 & 72,948 & 1,518 & 0,822 \\
\hline 2007 & 73,270 & 1,281 & 0,691 \\
\hline 2008 & 73,846 & 1,091 & 0,616 \\
\hline 2009 & 74,037 & 1,363 & 0,753 \\
\hline 2010 & 74,238 & 1,429 & 0,796 \\
\hline 2011 & 74,303 & 1,497 & 0,842 \\
\hline 2012 & 74,067 & 1,524 & 0,879 \\
\hline 2013 & 75,984 & 1,582 & 0,895 \\
\hline 2014 & 63,266 & 1,620 & 0,921 \\
\hline 2015 & 67,425 & 1,675 & 0,948 \\
\hline
\end{tabular}

Results of approximation and forecast FCE for the next 5 years

1. The first indicator Y1 (final energy consumption) is given in Table 2.

Table 2

Prediction of final consumption of energy (FCE) thousand t.o.e. by using the group method of data handling

\begin{tabular}{|c|r|r|r|r|r|r|r|r|r|}
\hline Year & $\mathbf{2 0 0 6}$ & $\mathbf{2 0 0 7}$ & $\mathbf{2 0 0 8}$ & $\mathbf{2 0 0 9}$ & $\mathbf{2 0 1 0}$ & $\mathbf{2 0 1 1}$ & $\mathbf{2 0 1 2}$ & $\mathbf{2 0 1 3}$ & $\mathbf{2 0 1 4}$ \\
\hline Table & 72,948 & 73,270 & 73,846 & 74,037 & 74,238 & 74,303 & 74,067 & 75,984 & 63,266 \\
\hline Model & & 71,247 & 71,721 & 71,518 & 71,312 & 71,104 & 70,892 & 70,677 & 70,458 \\
\hline
\end{tabular}


Continuation of Table 2

\begin{tabular}{|c|l|l|l|l|l|l|}
\hline Year & \multicolumn{1}{|c|}{$\mathbf{2 0 1 5}$} & $\mathbf{2 0 1 6}$ & $\mathbf{2 0 1 7}$ & $\mathbf{2 0 1 8}$ & $\mathbf{2 0 1 9}$ & $\mathbf{2 0 2 0}$ \\
\hline Table & 67,425 & & & & & \\
\hline Model & 70,237 & 69,335 & 69,632 & 69,398 & 69,160 & 68,919 \\
\hline
\end{tabular}

2. The second indicator Y2 - Primary energy intensity (total primary energy supply, t.o.e. / $€ 1000$ GDP) is given in Table 3.

Table 3

Prediction of primary energy intensity by using the group method of data handling

\begin{tabular}{|c|c|l|l|l|l|l|l|l|l|}
\hline Year & $\mathbf{2 0 0 6}$ & $\mathbf{2 0 0 7}$ & $\mathbf{2 0 0 8}$ & $\mathbf{2 0 0 9}$ & $\mathbf{2 0 1 0}$ & $\mathbf{2 0 1 1}$ & $\mathbf{2 0 1 2}$ & $\mathbf{2 0 1 3}$ & $\mathbf{2 0 1 4}$ \\
\hline Table & 1,518 & 1,281 & 1,091 & 1,363 & 1,429 & 1,497 & 1,524 & 1,582 & 1,620 \\
\hline Model & & 1,48 & 1,50 & 1,51 & 1,53 & 1,55 & 1,56 & 1,58 & 1,60 \\
\hline
\end{tabular}

Continuation of Table 3

\begin{tabular}{|c|l|l|l|l|l|l|}
\hline Year & \multicolumn{1}{|c|}{$\mathbf{2 0 1 5}$} & $\mathbf{2 0 1 6}$ & $\mathbf{2 0 1 7}$ & $\mathbf{2 0 1 8}$ & $\mathbf{2 0 1 9}$ & $\mathbf{2 0 2 0}$ \\
\hline Table & 1,675 & & & & & \\
\hline Model & 1,62 & 1,651 & 1,670 & 1,709 & 1,689 & 1,729 \\
\hline
\end{tabular}

3. The third indicator Y3 (final energy consumption (final energy consumption t.o.e. / $€$ 1000 GDP) are shown in Table 4.

Table 4

Prediction of final energy intensity (final energy consumption t.o.e. / $€ 1000$ GDP) by using the group method of data handling

\begin{tabular}{|c|c|c|c|c|c|c|c|c|c|}
\hline Year & 2006 & 2007 & 2008 & 2009 & 2010 & 2011 & 2012 & 2013 & 2014 \\
\hline Table & 0,822 & 0,691 & 0,616 & 0,753 & 0,796 & 0,842 & 0,879 & 0,895 & 0,921 \\
\hline Model & & 0,83 & 0,85 & 0,86 & 0,87 & 0,88 & 0,90 & 0,91 & 0,93 \\
\hline
\end{tabular}

Continuation of Table 4

\begin{tabular}{|c|l|l|l|l|l|l|}
\hline Year & \multicolumn{1}{|c|}{$\mathbf{2 0 1 5}$} & $\mathbf{2 0 1 6}$ & $\mathbf{2 0 1 7}$ & $\mathbf{2 0 1 8}$ & $\mathbf{2 0 1 9}$ & $\mathbf{2 0 2 0}$ \\
\hline Table & 0,948 & & & & & \\
\hline Model & 0,94 & 0,962 & 0,991 & 0,976 & 1,006 & 1,021 \\
\hline
\end{tabular}

Predictive System Model of FEC forecast for next year depends on the values of the last and before last year, offset (-1) and (-2)):

$$
\begin{aligned}
& Y 1=39,222+0,2496 * Y 1(-1)+0 * Y 1(-2)-29,210 * Y 2(-1)+ \\
& +178,642 * Y 2(-2)+0 * Y 3(-1)-354,418 * Y 3(-2) \\
& Y 2=0,0000+0 * Y 1(-1)+0 * Y 1(-2)+1,0316 * Y 2(-1)+ \\
& +0 * Y 2(-2)+0 * Y 3(-1)+0 * Y 3(-2) ; \\
& Y 3=0,0000+0 * Y 1(-1)+0 * Y 1(-2)+0,6410 * Y 2(-1)-0,0590 * Y 2(-2)+ \\
& +1.0149 * Y 3(-1)+0 * Y 3(-2) .
\end{aligned}
$$

Comment: Y1 depends on Y1 (-1), Y2 (-1), Y2 (-2) and Y3 (-2); Model is purely autoregressive Y2: Y2 depends on its previous value Y2 (-1); Y3 depends on Y2 (-1), Y2 (-2) and Y3 (-1)

Forecasted balance of Electricity

$$
\begin{aligned}
& \mathrm{Y} 1=0.3428 * \mathrm{Y} 1(-1)+0.722 * \mathrm{Y} 2(-1)+0.7087 * \mathrm{Y} 3(-1) \\
& \mathrm{Y} 2=0.3942 * \mathrm{Y} 1(-1)+0.5874 * \mathrm{Y} 2(-1) \\
& \mathrm{Y} 3=-11.4467+0.0847 * \mathrm{Y} 1(-1)+0.6787 * \mathrm{Y} 3(-1)
\end{aligned}
$$

Forecasting electricity consumption (gross) by using the group method of data handling are given in Table 5 
Prediction of electricity consumption (gross) by using the group method of data handling

\begin{tabular}{|c|c|c|c|c|c|c|c|c|c|}
\hline Year & $\mathbf{2 0 0 6}$ & $\mathbf{2 0 0 7}$ & $\mathbf{2 0 0 8}$ & $\mathbf{2 0 0 9}$ & $\mathbf{2 0 1 0}$ & $\mathbf{2 0 1 1}$ & $\mathbf{2 0 1 2}$ & $\mathbf{2 0 1 3}$ & $\mathbf{2 0 1 4}$ \\
\hline Table & 177.9 & 183.7 & 193.7 & 198.8 & 204.7 & 209.5 & 216.9 & 226.9 & 231 \\
\hline Model & & 181.6 & 186.8 & 192.3 & 198.2 & 204.6 & 211.4 & 218.7 & 226.6 \\
\hline
\end{tabular}

Continuation of Table 5

\begin{tabular}{|c|c|l|l|l|l|l|}
\hline Year & $\mathbf{2 0 1 5}$ & $\mathbf{2 0 1 6}$ & $\mathbf{2 0 1 7}$ & $\mathbf{2 0 1 8}$ & $\mathbf{2 0 1 9}$ & $\mathbf{2 0 2 0}$ \\
\hline Table & & & & & & \\
\hline Model & 235.1 & 243.9 & 253.2 & 263.7 & 275 & 287.2 \\
\hline
\end{tabular}

Prediction of electricity consumption (net) by using the group method of data handling are given in Table 6

Table 6

Prediction of electricity consumption (net) by using the group method of of data handling

\begin{tabular}{|c|c|c|c|c|c|c|c|c|c|}
\hline Year & $\mathbf{2 0 0 6}$ & $\mathbf{2 0 0 7}$ & $\mathbf{2 0 0 8}$ & $\mathbf{2 0 0 9}$ & $\mathbf{2 0 1 0}$ & $\mathbf{2 0 1 1}$ & $\mathbf{2 0 1 2}$ & $\mathbf{2 0 1 3}$ & $\mathbf{2 0 1 4}$ \\
\hline Table & 158.6 & 162.6 & 167.4 & 172.8 & 175.6 & 181.5 & 184.2 & 189.4 & 198.5 \\
\hline Model & & 163.3 & 167.5 & 172. & 176.9 & 182 & 187 & 193.5 & 199.9 \\
\hline
\end{tabular}

\begin{tabular}{|c|l|l|l|l|l|l|}
\hline Year & $\mathbf{2 0 1 5}$ & $\mathbf{2 0 1 6}$ & $\mathbf{2 0 1 7}$ & $\mathbf{2 0 1 8}$ & $\mathbf{2 0 1 9}$ & $\mathbf{2 0 2 0}$ \\
\hline Table & 208.5 & & & & & \\
\hline Model & 206.7 & 213.5 & 221.6 & 230 & 239 & 248.8 \\
\hline
\end{tabular}

Prediction of electricity export by the group method of data handling are given in Table 6

Table 7

Prediction of electricity export by the group method of data handling

\begin{tabular}{|c|l|l|l|l|l|l|l|l|l|}
\hline Year & $\mathbf{2 0 0 6}$ & $\mathbf{2 0 0 7}$ & $\mathbf{2 0 0 8}$ & $\mathbf{2 0 0 9}$ & $\mathbf{2 0 1 0}$ & $\mathbf{2 0 1 1}$ & $\mathbf{2 0 1 2}$ & $\mathbf{2 0 1 3}$ & $\mathbf{2 0 1 4}$ \\
\hline Table & 8.56 & 9.35 & 10.47 & 10.86 & 11.35 & 13.65 & 15.33 & 17.37 & 19.23 \\
\hline Model & & 9.43 & 10.33 & 11.39 & 12.57 & 13.88 & 15.3 & 16.84 & 18.51 \\
\hline
\end{tabular}

Continuation of Table 7

\begin{tabular}{|c|l|l|l|l|l|l|}
\hline Year & \multicolumn{1}{|c|}{$\mathbf{2 0 1 5}$} & $\mathbf{2 0 1 6}$ & $\mathbf{2 0 1 7}$ & $\mathbf{2 0 1 8}$ & $\mathbf{2 0 1 9}$ & $\mathbf{2 0 2 0}$ \\
\hline Table & 20 & & & & & \\
\hline Model & 20.31 & 21.69 & 23.94 & 26.24 & 28.7 & 31.33 \\
\hline
\end{tabular}

Prediction of energy consumption by using the group method of data handling:

$$
\begin{aligned}
& \mathrm{Y} 1=88.6897-2.0492 * \mathrm{Y} 3(-1) ; \\
& \mathrm{Y} 2=0.0823 * \mathrm{Y} 1(-1)-3.4666^{*} \mathrm{Y} 2(-1)+7.2614 * \mathrm{Y} 3(-1) \\
& \mathrm{Y} 3=4.2195-2.2605 * \mathrm{Y} 2(-1)+4.5343 * \mathrm{Y} 3(-1)
\end{aligned}
$$

Conclusions. Through analysis of the dynamics of electricity consumption in Ukraine and analysis of such important indicators as the final energy consumption, primary energy consumption, the export of electricity consumption (net) electricity consumption (gross) final consumption of energy - were built predictive models in the energy sector through the use group method of data handling for the above indicators and made the following results:

- predicted the increase of final energy intensity from 8.22 t.n.e. / $€ 1000$ of GDP in 2005 to 9,52 t.n.e. / $€ 1000$ of GDP in 2020 ;

- predicted the increase of primary energy intensity from 15,18 t.n.e. / $€ 1000$ of GDP in 2005 to 16.74 t.n.e. / $€ 1,000$ of GDP in 2020;

- predicted the increase electricity exports from 8,56 in 2005 to 31,33 in 2020;

- predicted the growth of electricity consumption (net) from 158,6 in 2005 to 258,8 in 2020;

- predicted the growth of electricity consumption (gross) from 177,9 in 2005 to 287,2 in 2020; 
- predicted the reduction of final consumption of electricity (FCE) from 72.95 thousand $t$ o.e. in 2005 to 68,91 thousand t.o.e. in 2020 .

\section{Список використаних джерел}

1. Ивахненко А. Г. Принятие решений на основе самоорганизации / А. Г. Ивахненко, Ю. П. Зайченко, В. Д. Димитров. - М. : Советское радио, 1976. - 280 с.

2. Кравець I. О. Дослідження методів статистичного та інтелектуального аналізу для авторегресійних моделей / I. О. Кравець, Г. О. Афанасьєва // Наукові праці : науково-методичний журнал. - Миколаїв : Вид-во ЧДУ ім. Петра Могили, 2009. - Вип. 93. - С. 54-62.

3. Економічна безпека регіону: єдність теорії, методології дослідження і практики / А. И. Татаркин, А. А. Куклин, О. А. Романова та ін. - Скатеринбург : Урал. 2007. - 240 с.

4. Савенко Ю. Н. Енергетичний баланс. Деякі питання теорії і практики / Ю. Н. Савенко, Е. О. Штейнгауз. - М. : Енергія, 2011. - 184c.

5. Дмитриевский А. Н. Электроэнергетика в XXI веке / А. Н. Дмитриевский // Энергетическое хозяйство. - 2002. - № 12. - С. 14-17.

6. Котлер В. Р. Потребление первичной энергии и структура топливопотребления в мире / В. Р. Котлер // Электрические станции. - 2002. - № 7. - С. 71.

\section{References}

1. Ivahnenko, A.G., Zaichenko, Iu.P., Dimitrov, V.D. (1976). Priniatie reshenii na osnove samoorganizatsii [Making decisions based on self-organization and adoption]. Moscow: Soviet Radio.

2. Kravets, I.O., Afanasyeva, G.A. (2009). Doslidzhennia metodiv statystychnoho ta intelektualnoho analizu dlia avtorehresiinykh modelei [Research methods of statistical and predictive analysis for autoregressive models]. Naukovi pratsi : naukovo-metodychnyi zhurnal-Scientific Papers: Scientificmethodical journal. Mykolaiv, vol. 93, pp. 54-62.

3. Tatarkyn, A.I., Kuklin, A.A., Romanov, A.A. et al. (2007). Ekonomichna bezpeka rehionu: yednist teorii, metodolohii doslidzhennia i praktyky [The economic security of the region: the unity of theory, research methodology and practice]. Ekaterinburg: Urals.

4. Savenko, Yu.N., Shteinhauz, E.O. (2011). Enerhetychnyi balans. Deiaki pytannia teorii i praktyky [Energy balance. Some questions of theory and practice]. Moscow: Enerhiia.

5. Dmytryevskyy, A.N. (2002). Electricity in the XXI century [Elektroenergetika v XXI veke]. Energeticheskoe khoziaistvo - Electric energy, no. 12, pp. 14-17.

6. Kotler, V.R. (2002). Potreblenie pervichnoi energii i struktura toplivopotrebleniia v mire [Consumption of primary energy and structure in the world energy consumption]. Elektricheskie stantsii Electric stations, no. 7, pp. 71.

Степашко Володимир Семенович - доктор технічних наук, професор кафедри ММСА, НТУУ "КПІ"

ім. I Сікорського (просп. Перемоги, 37, м. Київ, 03056, Україна).

Степашко Владимир Семенович - доктор технических наук, профессор кафедры ММСА, НТУУ "КПІ'

им. И. Сикорского (просп. Победы, 37, г. Киев, 03056, Украина).

Stepashko Volodymyr - Doctor of Technical Sciences, professor of Department of MMSA, NTUU "Igor Sikorsky

Kyiv Polytechnic Institute" (37 Peremohy Av., 03056 Kyiv, Ukraine).

E-mail:vsstepashko@i.ua

Трачук Андрій Романович - аспірант кафедри АУЕК, IEE НТУУ «КПІ» ім. І.Сікорського (просп. Перемоги, 37, м. Київ, 03056, Україна).

Трачук Андрей Романович - аспирант кафедры АУЭК, ИЭЭ НТУ «КПИ» им. И. Сикорского (просп. Победы, 37, г. Киев, 03056, Украина).

Andrii Trachuk - PhD student of Department of Automation Management of Electrotechnical Complexes Institute of Energy Saving and Energy Management (IEE), NTUU "Igor Sikorsky Kyiv Polytechnic Institute" (37 Peremohy Av., 03056 Kyiv, Ukraine).

E-mail: matrix@i.ua 